\title{
Impact of Trichogramma chilonis on Tomato fruit worm (Helicoverpa Armigera Hub.) in Tomato crop
}

\author{
Numan Nisar*, Syed Fahad Shah, Jawad Sarwar, Fazli Amin and \\ Inam Rasheed \\ Department of Entomology, University of Agriculture, Peshawar-Pakistan \\ *Corresponding author's email: numannisar313@gmail.com \\ Citation \\ Numan Nisar, Syed Fahad Shah, Jawad Sarwar, Fazli Amin and Inam Rasheed. Impact of Trichogramma \\ chilonis on Tomato fruit worm (Helicoverpa Armigera Hub.) in Tomato crop. Pure and Applied Biology. Vol. 9, \\ Issue 1, pp443-447. http://dx.doi.org/10.19045/bspab.2020.90048
}

\begin{tabular}{llll}
\hline \hline Received: 22/05/2019 & Revised: 31/10/2019 & Accepted: 11/11/2019 & Online First: 15/11/2019 \\
\hline \hline
\end{tabular}

\section{Abstract}

To find out the effect of different density levels of Trichogramma chilonis against tomato fruit borer Helicoverpa armigera, an experiment was carried out at Agriculture Research Institute (ARI), Tarnab Peshawar during summer 2016. Experiment was laid out in Randomized Complete Block design consisted of four treatments including control was replicated five times each treatment having plot size $8 \times 5 \mathrm{~m} 2$. Parasitized eggs of T. chilonis were taken in the following numeral T1 (400), T2 (800) and T3 (1200) and were applied twice respectively. Pest infestation, percent weight loss in fruits and yield data were recorded on different intervals. Results showed that the larval infestation of $\mathrm{H}$. armigera varied according to the released level of the parasitoid. Minimum infestation $(0.50) \mathrm{H}$. armigera larvae plant1 was recorded in T3 followed by T2 (0.62), T1 (1.00). As maximum infestation were recorded in control (3.40). Higher yield of tomato was recorded in T3 (9160 kg ha-1) and lower in control (5920 kg ha-1). Similarly, lowest percent weight loss was recorded in T3 (12.40\%) and maximum in control (43.58\%). Based on lower larval infestation, minimum percent weight loss and higher yield, treatment T3 (1200 parasitized eggs) is here by recommended for the safe and effective management of $\mathrm{H}$. armigera in tomato crop. The study was focused on reducing $\mathrm{H}$. armigera infestation, increase in tomato yield and attain environmental safety by means of T. chilonis.

Keywords: Biopesticide; Helicoverpa armigera; Tomato; Trichogramma chilonis

\section{Introduction}

Tomato, Lycopersicum escolentum Mill, is one of the vital and broadly used vegetable crop which belongs to family Solanaceae. It is full of nutrients and delightful; very limited vegetables have such nutritional value. Tomato is the most significant vegetable crop cultured for its fleshful fruits and known as an important profitable and nutritive [1]. Tomato crop is cultivated in all areas of Pakistan. Different varieties of tomatoes are grown at 52,300 hectors area and the estimated production in 2011-2012 was 530,000 tones. Whereas cultivated area in Khyber Pakhtunkhwa during 2011- 2012 was 12,600 hectors with a production of 113200 tons [2].

In Pakistan tomato crop have minimum production. Factors responsible for its low production such as insect pests, diseases and poor seed quality. Among them insects pests have been reported for high yield loss [3]. In insects Helicoverpa armigera (Hubner) (Lepidoptera: Noctuidae) is the major pest which responsible for greater losses [4]. H. armigera infested 32-35\% tomato fruit in Pakistan [5]. In Peshawar, Khyber Pakhtunkhwa province 53\% of tomato fruit damage was observed by Inayatullah [6]. 
H. armigera is the main pest which attacks many crops in Pakistan, such as Tomato, Chickpea, cotton as well as pigeon pea. These crops are constantly damaged by $H$. armigera, as the larval stage induce infestation and cause severe injury to tomato fruit and decrease its yield. Adult of the $H$. armigera generally lays eggs on leaves during the month of April and May. Larvae damage the leaves as well as flower and destroy the fruit of tomato. Damage caused by larva hinders the value of tomato fruit in the market and farmer faces large scale losses [7].

Parasitoids such Trichogramma chilonis are in lime light due to its efficient predation capability [8]. T. chilonis is a tiny wasp which belongs to the family Trichogrammatidae, this family has a wider host range and particularly feed on Lepidoptera. After the parasitization of lepidopteran eggs it turns black because of the internal development of the parasitoid and eventually adult wasp emerge from these parasitized black eggs [9]. Purpose of this study is to attain such a management pattern that can help in effective control $H$. armigera through $T$. chilonis and increase the tomato fruit production.

\section{Materials and methods}

Field experiment was carried out at Agriculture Research Institute (ARI) Tarnab, Peshawar in 2016. Mass production of $T$. chilonis for purpose of its release in field was performed as following. Preparation of Sitotroga cerealella culture as host of Trichogramma chilonis Fresh eggs of Sitotroga cerealella were brought from Nuclear Institute of Food and Agriculture Peshawar (NIFA) and were observed for mites infestation under microscope. Eggs having dark red colour were introduced in to the glass jars having sterilized wheat grains. In the laboratory, the jars were kept at $25^{\circ} \mathrm{C} \pm 22^{\circ} \mathrm{C}$ temperature and $60 \pm 5 \%$ R.H for the development of $S$. cerealella. When adult $S$. cerealella of emerged, vacuum pump was used for the collection of adults from jars and then transferred to plastic jars having wire gauze at the bottom. Jars having wire gauze at the bottom were placed in wheat flour where adults laid eggs. Wheat flour placed under plastic jar of adults was taken and sieved through mesh size of $80 \mathrm{~mm}$ in order to get the eggs after that were sieved through mesh size of 60 to get the egg clusters. In this way fresh eggs of $S$. cerealella were easily available to Trichogramma for the purpose of parasitization.

\section{Rearing of Trichogramma chilonis}

Fresh eggs of $S$. cerealella were collected and were transferred to plastic bottle covered with muslin cloth. Hard paper of size ( $2 \times 3$ Inch) was glued and eggs of $S$. cerealella were sprinkled thoroughly over hard paper. These cards were left for sometime in order to dry and then placed in glass jar for $24 \mathrm{~h}$ having $T$ chilonis culture. After passage of 24 hours old cards were replaced with new cards having $S$. cerealella to the jar of $T$ chilonis culture for the purpose of parasitization. In order to get $T$. chilonis culture in a smooth way, the process was repeated on daily basis.

\section{Field preparation}

Using normal cultural practices field was prepared for tomato. $\mathrm{F}_{1}$ hybrid variety was used for trial. For the conduction of experiment the field was ploughed twice and seed beds were prepared in a good way in order to get good crop. Layout of experiment was Randomized Complete Block Design (RCBD) which consisted of five replications. Every replication consisted of three treatments and control. Plot size was $8 \times 5 \mathrm{~m}^{2}$ and a buffer zone of 3 meters between each treatment was maintained. Among the replications distance of 2 meters was kept.

\section{Transplantation of tomato crop}

Transplantation of tomato plants were done in the month of March before the initiation of flowering stage.

\section{Release treatments}

T. chilonis were applied twice in three treatments composition $\mathrm{T}_{1}$ (400), $\mathrm{T}_{2}$ (800) and $\mathrm{T}_{3}$ (1200) eggs). Interval of one month 
was kept between $1^{\text {st }}$ and $2^{\text {nd }}$ application of T. chilonis.

\section{Data collection}

Six plants were randomly selected plot $^{-1}$ and number of eggs and larvae were recorded on the selected plants after one week interval. Ripened tomato fruits were collected from each plot separately, weight and number of fruits were recorded individually for each plot. Fruits which are damaged were weighed. By the addition of all tomato pickings total yield was recorded. The following formulas were used:

$$
\begin{gathered}
\text { Yield }\left(\mathrm{kg} \mathrm{ha}^{-1}\right)=\frac{\text { Yield plot }^{-1}}{\text { Plot size }\left(\mathrm{m}^{2}\right)} \times 10000 \\
\text { Percent weight loss }=\frac{\text { Weight of damaged fruits }}{\text { Total Weight of tomato fruits }} \times 100
\end{gathered}
$$

\section{Data analysis}

Experiment was laid out in Randomized Complete Block Design (RCBD). Collected data was subjected to ANOVA and means were separated using LSD test (Statistix ver 8.1).

\section{Results and discussion}

Efficacy of different $T$. chilonis treatments were tested against tomato fruit borer $(H$. armigera) under field conditions at Agriculture Research Institute Tarnab, Peshawar during summer 2016.

\section{Application of T. chilonis}

Data were collected on 6 randomly selected plants per plot by observing number of $H$. armigera larvae started from $1^{\text {st }}$ April 2016. Results in the table 1 revealed that in pre treatment data the number of $H$. armigera larvae plant ${ }^{-1}$ recorded were 2.66, 2.72, 2.68, 2.60 in $\mathrm{T}_{1}, \mathrm{~T}_{2}, \mathrm{~T}_{3}$ and in $\mathrm{T}_{4}$ check plot respectively. One week after application of Trichogramma, a maximum decline in mean population of fruit borer plant $^{-1}$ was recorded in $\mathrm{T}_{3}$ (2.52) followed by $\mathrm{T}_{2}$ (2.58) and then $T_{1}(2.60)$, while significantly high population was recorded in check plots $\mathrm{T}_{4}$ (2.86). Again no significant difference was found among $\mathrm{T}_{1}, \mathrm{~T}_{2}, \mathrm{~T}_{3}$ and control. During the $2^{\text {nd }}$ week after treatment significant decline in tomato borer mean population plant $^{-1}$ was observed among the treated and control plots. Data recorded revealed that the population of fruit borer plant $^{-1}$ in $\mathrm{T}_{1}, \mathrm{~T}_{2}$ and $\mathrm{T}_{3}$ were (2.38), (2.34) and (2.28) respectively. Among $T_{1}, T_{2}$ and $T_{3}$ no significant variance was recorded, while control plot was significantly different from the rest. Data recorded in $3^{\text {rd }}$ week showed increased effectiveness by $T$. chilonis, where larval population plant ${ }^{-1}$ in $T_{1}, T_{2}$ and $\mathrm{T}_{3}$ were (2.28), (2.20) and (2.16), while in control plots mean population of (3.54) larvae plant $^{-1}$ was noted.

\section{$2^{\text {nd }}$ Application of $T$. chilonis}

Data in the table 1 revealed that before $2^{\text {nd }}$ application $T$. chilonis high mean population of larvae plant $^{-1} 3.60$ was observed in control, while low mean pest density 2.02 larvae plant ${ }^{-1}$ was recorded in $\mathrm{T}_{3}$ followed by $\mathrm{T}_{2}(2.10)$ and $\mathrm{T}_{3}(2.22)$ respectively. Data recorded after 1 week of Trichogramma release, the results show that decline was recorded in pest population in treated plots. In $\mathrm{T}_{1} H$. armigera population varied from 2.22 to 2.00 . While in $\mathrm{T}_{2}$ pest density decreased from 2.10 to 1.80 and in $\mathrm{T}_{3}$ population decline recorded was from 2.02 to 1.52 larvae plant ${ }^{-1}$. It was revealed that there was no significant difference among treatments. During $2^{\text {nd }}$ week after release, decrease in pest density continued. Mean larval population plant ${ }^{-1}$ in $\mathrm{T}_{1}, \mathrm{~T}_{2}$ and $\mathrm{T}_{3}$ were $1.52,1.26$ and 0.98 respectively. During $3^{\text {rd }}$ week decline in mean larvae population of tomato fruit borer plant ${ }^{-1}$ was observed in all treatments and control plots. Mean larval population of $H$. armigera plant ${ }^{-1}$ recorded in $\mathrm{T}_{1}, \mathrm{~T}_{2}$ and $\mathrm{T}_{3}$ were $1.00,0.62$ and 0.50 respectively. It was observed that $\mathrm{T}_{3}$ was the most effective in reducing $H$. armigera larval population in comparison to the other treatments.

Piao and Yan [10] indicated that the presence of large number of parasitoids at 
the time of pest occurrence will insure maximum parasitism. Presence of great number of parasitoid also increases the persistency of parasitoid wasps in the field conditions and hence maximizes the chances of parasitism and synchronization. Rajput et al. [11] applied increasing number of Trichogramma wasp which resulted in fall of tomato borer. As the number of parasitoid wasp is released in large number maximum decline in tomato borer population was found, which is similar to our study. Our results are in agreement with Hou et al. [12] who observed that parasitism percentage of $T$. chilonis over $H$. armigera in laboratory conditions. Results showed that parasitism level ranged from $72.2 \%$ to $97.6 \%$ which clearly indicates that if proper release program is planned and applied in a scientific way $T$. chilonis can effectively control $H$. armigera. Ahmad et al. [13] carried out an experiment on suppressing the population of sugarcane stem borer (Chilo infuscatellus) through $T$. chilonis. $T$. chilonis was most effective in reducing $H$. armigera population from (25.95 to 9.31) $\%$. Similar observations were made by Puneeth and Vijayan [14] conducted a rearing experiment of $T$. chilonis on $H$. armigera and found that $T$. chilonis can be successfully reared on $H$. armigera and recorded parasitism of $58.54 \%, 93 \%$ hatchability and adult longevity of more than 6 days.

Table 1. Effect of T. chilonis treatments against $H$. armigera larval population in 2016

\begin{tabular}{|c|c|c|c|c|c|c|c|c|}
\hline \multirow{2}{*}{ Treatment } & \multicolumn{4}{|c|}{$\mathbf{1}^{\text {st }}$ Release } & \multicolumn{4}{|c|}{$\mathbf{2}^{\text {nd }}$ Release } \\
\cline { 2 - 9 } & $\begin{array}{c}\text { Before } \\
\text { Release }\end{array}$ & $\begin{array}{c}\mathbf{1}^{\text {st }} \\
\text { week }\end{array}$ & $\begin{array}{c}\mathbf{2}^{\text {nd }} \\
\text { week }\end{array}$ & $\begin{array}{c}\mathbf{3}^{\text {rd }} \\
\text { week }\end{array}$ & $\begin{array}{c}\text { Before } \\
\text { Release }\end{array}$ & $\mathbf{1}^{\text {st }}$ week & $\begin{array}{c}\mathbf{2}^{\text {nd }} \\
\text { week }\end{array}$ & $3^{\text {rd }}$ week \\
\hline $\mathrm{T}_{1}$ & 2.66 & 2.60 & $2.38 \mathrm{~b}$ & $2.28 \mathrm{~b}$ & 2.22 & $2.00 \mathrm{~b}$ & $1.52 \mathrm{~b}$ & $1.00 \mathrm{~b}$ \\
\hline $\mathrm{T}_{2}$ & 2.72 & 2.58 & $2.34 \mathrm{~b}$ & $2.20 \mathrm{~b}$ & 2.10 & $1.80 \mathrm{~b}$ & $1.26 \mathrm{~b}$ & $0.62 \mathrm{bc}$ \\
\hline $\mathrm{T}_{3}$ & 2.68 & 2.52 & $2.28 \mathrm{~b}$ & $2.16 \mathrm{~b}$ & 2.02 & $1.52 \mathrm{~b}$ & $0.98 \mathrm{~b}$ & $0.50 \mathrm{c}$ \\
\hline Control & 2.60 & 2.86 & $3.48 \mathrm{a}$ & $3.54 \mathrm{a}$ & 3.60 & $3.72 \mathrm{a}$ & $3.82 \mathrm{a}$ & $3.40 \mathrm{a}$ \\
\hline LSD value & & 0.98 & 0.92 & 0.84 & & 0.56 & 0.68 & 0.46 \\
\hline
\end{tabular}

Means in columns followed by dissimilar letters are statistically different at $\alpha=0.05$ (LSD Test)

$\mathrm{T}_{1}=(400)$ eggs, $\mathrm{T}_{2}=(800)$ eggs, $\mathrm{T}_{3}=(1200)$ eggs

Yield data

Data in table 2 shows the result of mean yield and \% weight loss after release of different $T$. chilonis densities against tomato fruit borer. Maximum yield (9160 $\mathrm{kg} \mathrm{ha}{ }^{-1}$ ) was recorded for $\mathrm{T}_{3}$ while minimum yield (5920 $\left.\mathrm{kg} \mathrm{ha}^{-1}\right)$ was recorded in control plot. Table 2 further reveals percent weight loss, minimum percent weight loss $(12.40 \%)$ was reported from $\mathrm{T}_{3}$ while minimum percent weight loss $(43.58 \%)$ was reported from control. Usman et al. [15] found high yield $(8428 \mathrm{~kg}$ $\mathrm{ha}^{-1}$ ) by application of $T$. chilonis eggs which shows that use of $T$. chilonis eggs can aid in obtaining higher yield.

Table 2. Yield $\left(\mathrm{kg} \mathrm{ha}^{-1}\right)$ and percent weight loss

\begin{tabular}{|c|c|c|}
\hline Treatment & Yield kg ha & $\mathbf{- 1}$ \\
\hline $\mathrm{T}_{1}$ & $6920 \mathrm{~b}$ & $(\boldsymbol{\%})$ Weight loss \\
\hline $\mathrm{T}_{2}$ & $7520 \mathrm{ab}$ & $20.24 \mathrm{~b}$ \\
\hline $\mathrm{T}_{3}$ & $9160 \mathrm{a}$ & $15.10 \mathrm{bc}$ \\
\hline Control & $5920 \mathrm{~b}$ & $12.40 \mathrm{c}$ \\
\hline LSD value & 1.09 & $43.58 \mathrm{a}$ \\
\hline
\end{tabular}

Means in columns followed by dissimilar letters are statistically different at $\alpha=0.05$ (LSD Test)

$\mathrm{T}_{1}=(400)$ eggs, $\mathrm{T}_{2}=(800)$ eggs, $\mathrm{T}_{3}=(1200)$ eggs

Conclusion

From the current study it is cleared that use of $T$. chilonis in higher concentration against $H$. armigera resulted effective control in field condition. It is recommended to release appropriate numeral of eggs in field on regular interval in order to reduce $H$. armigera, larval population to achieve higher tomato yield and 
environmental safety through use of biopesticide.

\section{Author's contributions}

Conceived and designed the experiments: $\mathrm{N}$ Nisar \& SF Shah, Performed the experiments N Nisar \& I Rasheed, Analyzed the data: F Amin \& J Sarwar, Wrote the paper: N Nisar.

\section{References}

1. Kevany BM, Taylor MG \& Klee HJ (2008). Fruit specific suppression of the ethylene receptor results in early-ripening tomato fruit. Pl Biotech J 6(3): 295-300.

2. Agriculture Statistics of Pakistan (20112012). Govt Pakistan Ministry of Food and Agriculture.

3. Hoffmann H, Hardie D \& Burt J (2007). Tomato pests in the home garden and their control. Dept Agric Aust Garden Note 34: 82-88.

4. Talekar NS, Opena RT \& Hanson P (2006). Helicoverpa armigera management: a review of AVRDC's research on host plant resistance in tomato. Crop Prot 25(5): 461-467.

5. Latif M, Ahecr GM \& Saeed M (1997). Quantitative losses in tomato fruits by Heliothis armigera $\mathrm{Hb}$. Third Int Congr Entomol Sci by Pak Entomol Soc 18-20.

6. Inayatullah M (2007). Biological control of tomato fruit worm (Helicoverpa armigera) using egg parasitoid Trichogramma chilonis (Trichogrammatidae: Hymenoptera) and Chrysoperla carnea (Chrysopidae: Neuroptera). First Annual Technical Report, HEC Funded Project, pp 99.

7. Hussain B \& Bilal S (2007). Efficacy of different insecticides on tomato fruit borer Helicoverpa armigera. J Entomol 4(1): 64-67.

8. Parra JR \& Zucchi RA (2004). Trichogramma in Brazil: feasibility of use after twenty years of research. Neotrop Entomol 33(3): 271-281.

9. Bigler F, Suverkropp BP \& Cerutti F (1997). Host searching by Trichogramma and its implications for quality control and release techniques. Westview Press, Boulder 15: 240-253.

10. Piao YF \& Yan S (1996). Progress of mass production and field application of Trichogramma dendrolimi. In Proceedings of the National Symposium on IPM in China, ZL Zhang, YF Piao and JW Wu, eds., China Agric Sci Press, Beijing pp. 1135-1136.

11. Rajput IA, Qureshi KH, Khuhro TA, Khuhro RD, Khanzada SH \& Lashario IA (2015). Effect of Different Densities of Trichogramma chilonis (Ishii) against Lepidopteran Pests on Tomato. Eur Acad Res 2(10): 13494-13504.

12. Hou M, Wang F, Wan F \& Zhang F (2006). Parasitism of Helicoverpa assulta Guenée (Lepidoptera: Noctuidae) eggs by Trichogramma spp. (Hymenoptera: Trichogrammatidae): Implications for inundative release on tobacco plants. App Entomol Zool 41(4): 577-584.

13. Ahmad S, Ashfaq M, Hassan M \& Sahi ST (2012). Potential of parasitoid Trichogramma chilonis (Ishii) (Hymenoptera: Trichogrammatidae) against the sugarcane stem borer, Chilo infuscatellus (Lepidoptera; Pyralidae) under field conditions. Inter $J$ Biod Conserv 4(1): 36-38.

14. Puneeth P \& Vijayan VA (2014). Parasitization Capacity of Trichogramma chilonis Ishii (Hymenoptera: Trichogrammatidae) on the Eggs of Helicoverpa Armigera (Lepidoptera: Noctuidae) under Laboratory Conditions. Inter J Adv Biol Res 5(3): 462-465.

15. Usman M, Inayatullah M, Usman A, Sohail K \& Shah SF (2012). Effect of egg parasitoid, Trichogramma chilonis in combination with Chrysoperla carnea and neem seed extract against tomato fruit worm, Helicoverpa armigera. Sarhad J Agric 28(2): 253-257. 